Syntax Idea: p-ISSN: 2684-6853 e-ISSN: 2684-883X

Vol. 3, No.11, November 2021

\title{
IMPLEMENTASI MODEL PEMBELAJARAN COOPERATIVE LEARNING TYPE STAD DENGAN PENDEKATAN KONTEKSTUAL UNTUK MENINGKATKAN KEMAMPUAN SISWA DALAM MEMAHAMI TRIGONOMETRI
}

\section{Inan Nurrofiq}

SMAN 1 Sukapura, Kab.Probolinggo Jawa Timur, Indonesia

Email: inannurrofiq@gmail.com

\begin{abstract}
Abstrak
SMA Negeri 1 Sukapura pada kelas X MIA memiliki masalah pembelajaran pada mata pelajaran Matematika yaitu materi Trigonometri. Pada siswa Kelas X MIA SMA Negeri 1 Sukapura banyak siswa belum memahami terhadap materi yang di sampaikan guru Matematika. Rendahnya pemahaman siswa terhadap Trigonometri disebabkan siswa kesulitan memahami materi yang disampaikan oleh guru. Siswa tidak terlibat aktif dalam pembelajaran dan sulit untuk memperoleh pemahaman yang mendalam. Hal ini berakibat kemampuan siswa dalam Memahami Trigonometri .Oleh karena itu penelitian ini mengambil judul "Implementasi Model Pembelajaran Cooperative Learning type STAD dengan Pendekatan Kontekstual Untuk Meningkatkan Kemampuan Siswa Dalam Memahami Trigonometri di Kelas X MIA SMA Negeri 1 Sukapura Tahun Pelajaran 2017/2018" Model Pembelajaran Cooperative Learning type STAD memlaui Pendekatan Kontekstual merupakan metode mengajar yang menekankan pada aktivitas dan interaksi diantara siswa untuk saling memotivasi dan saling membantu dalam menguasai materi pelajaran guna mencapai prestasi yang maksimal dengan menghadirkan situasi dunia nyata ke dalam kelas . Perbandingan hasil penelitian yaitu pada pra siklus jumlah siswa yang tuntas belajar hanya 19 siswa atau $76 \%$, kemudian pada siklus 1 meningkat menjadi 20 siswa atau $80 \%$, dan meningkat pada siklus 2 menjadi 22 siswa atau 88\%. Dari perbandingan hasil penelitian tersebut maka dapat di simpulkan bahwa, dengan konsep $4 \mathrm{X}$ pertemuan maka Pembelajaran model Cooperative Learning type STAD dengan Pendekatan Kontekstual berdampak positif bagi proses peningkatan kemampuan siswa dalam memahami Trigonometri.
\end{abstract}

Kata Kunci: model pembelajaran koperasi STAD; pendekatan kontekstual; kemampuan siswa untuk memahami trigonometri

\section{Abstract}

SMA Negeri 1 Sukapura in class X MIA has learning problems in Mathematics, namely Trigonometry. In Class X MIA SMA Negeri 1 Sukapura, many students do not understand the material presented by the Mathematics teacher. The low understanding of students towards Trigonometry is caused by students having difficulty understanding the material presented by the teacher., Students are not actively involved in learning and it is difficult to gain deep understanding. This results in students' ability to understand trigonometry. Therefore, this study takes

\begin{tabular}{ll} 
How to cite: & $\begin{array}{l}\text { Nurrofiq, I.,(2021) Implementasi model pembelajaran cooperative learning type stad dengan pendekatan } \\
\text { kontekstual untuk meningkatkan kemampuan siswa dalam memahami trigonometri, Syntax Idea, 3(11), }\end{array}$ \\
& https:// doi.org/10.36418/syntax-idea.v3i11.1578 \\
$\begin{array}{l}\text { E-ISSN: } \\
\text { Published by: }\end{array}$ & 2684-883X \\
\hline
\end{tabular}


the title "Implementation of STAD type Cooperative Learning Learning Model with a Contextual Approach to Improve Students' Ability to Understand Trigonometry in Class X MIA SMA Negeri 1 Sukapura Academic Year 2017/2018" Learning Model Cooperative Learning type STAD through a Contextual Approach is a teaching method that emphasizes activities and interactions between students to motivate each other and help each other in mastering the subject matter in order to achieve maximum performance by presenting real-world situations into the classroom. Comparison of research results, namely in the pre-cycle the number of students who finished studying was only 19 students or $76 \%$, then in cycle 1 it increased to 20 students or $80 \%$, and increased in cycle 2 to 22 students or $88 \%$. From the comparison of the results of the study, It can be concluded that, with the concept of $4 X$ meetings, the STAD Cooperative Learning model learning with a Contextual Approach has a positive impact on the process of increasing students' ability to understand Trigonometry.

Keywords: STAD Cooperative Learning Model; Contextual Approach; Students' Ability to Understand Trigonometry

Received: 2021-10-22; Accepted: 2021-11-05; Published: 2021-11-20

\section{Pendahuluan}

Kegiatan beiajar mengajar adalah suatu proses interaksi atau hubungan timbal balik antara guru dan siswa dalam satuan pembelajaran. Guru sebagai salah satu komponen dalam proses belajar mengajar merupakan pemegang peran yang sangat penting. Guru bukan hanya sekedar penyampai materi saja, tetapi lebih dari itu guru dapat dikatakan sebagai sentral pembelajaran (Tkalčič, 2012).

Sebagai pengatur sekaligus pelaku dalam proses belajar mengajar, gurulah yang mengarahkan bagaimana proses belajar mengajar itu dilaksanakan. Guru mengemban tugas yang berat untuk tercapainya tujuan pendidikan nasional yaitu Berhasilnya tujuan pembelajaran ditentukan oleh banyak faktor di antaranya adalah faktor guru dalam melaksanakan proses belajar mengajar, karena guru secara langsung dapat mempengaruhi, membina dan meningkatkan kecerdasan serta keterampilan siswa. Untuk mengatasi permasalahan di atas dan guna mencapai tujuan pendidikan secara maksirnal, peran guru sangat penting dan diharapkan guru memiliki cara/model mengajar yang baik dan mampu memilih model pembelajaran yang tepat dan sesuai dengan konsep-konsep mata pelajaran yang akan disampaikan agar prestasi belajar dan kemampuan yang diperoleh siswa mampu meningkat secara terus-menerus (Hamsi, 2016).

Kegiatan belajar mengajar merupakan proses interaksi atau hubungan timbal balik antara guru dan siswa dalam satuan pembelajaran Guru bukan lagi sebagai pusat pembelajaran, melainkan bertindak sebagai fasilitator dan motivator. Peran guru sebagai fasilitator dan motivator sangat diperlukan dalam setiap pembelajaran, termasuk dalam pembelajaran Matematika (Khasanah et al., 2020). 
Matematika merupakan mata pelajaran yang dikaji oleh setiap jenjang kelas di sekolah. Termasuk juga di kelas X MIA pada tingkat Sekolah Menengah Atas. Salah satu materi Matematika yang di ajarkan di kelas X MIA adalah Trigonometri. Pada materi ini siswa di harapkan dapat memahami Trigonometri yang di-ciptakan di daerah setempat (Palayukan, 2018).

Pada kelas X MIA SMA Negeri 1 Sukapura terdapat masalah pembelajaran pada mata pelajaran Matematika khususnya materi Trigonometri. Pada siswa kelas X MIA SMA Negeri 1 Sukapura banyak siswa yang belum memahami betul terhadap materi yang di sampaikan guru Matematika. Rendahnya pemahaman siswa terhadap Trigonometri disebabkan siswa mengalami kesulitan dalam memahami materi yang disampaikan oleh guru. Salah satu usaha yang dapat dilakukan untuk mengatasi masalah yang terjadi pada siswa kelas X MIA SMA Negeri 1 Sukapura adalah dengan memaksimalkan keaktifan siswa dalam KBM menggunakan Model Pembelajaran Cooperative Learning type STAD dengan Pendekatan Kontekstual merupakan alternative solusi.

\section{Metode Penelitian}

Pokok bahasan dalam Penelitian ini adalah "Implementasi Model Pembelajaran Cooperative Learning type STAD dengan Pendekatan Kontekstual Untuk Meningkatkan Kemampuan Siswa Dalam Memahami Trigonometri di Kelas X MIA SMA Negeri 1 Sukapura Tahun Pelajaran 2017/2018". Jadi, Penelitian tindakan kelas (PTK) ini dilaksanakan di Kelas X MIA SMA Negeri 1 Sukapura dengan jumlah peserta didik 25 siswa.

Adapun rancangan yang digunakan dalam penelitian ini adalah menggunakan Penelitian Tindakan Kelas (Classromm Activity Research). Pelaksanaan tindakan dalam PTK meliputi empat alur (langkah): (1) perencanaan tindakan; (2) pelaksanaan tindakan; (3) Pengamatan; (4) refleksi (Yusuf \& Asrifan, 2020).

\section{Hasil dan Pembahasan}

\section{A. Hasil Penelitian}

\section{Prosedur Penelitian Pra Siklus}

Tahap pra siklus ini di laksanakan pada tanggal 20 Januari 2018, bertujuan untuk mengetahui kondisi awal siswa sebelum di terapkan model pembelajaran Cooperative Learning type STAD dengan Pendekatan Kontekstual dengan tahapan sebagai berikut (Novita, 2021):

1) Perencanaan

Membuat instrument penelitian yang terdiri dari lembar observasi kemampuan siswa dalam memahami Trigonometri, pedoman wawancara, dan penilaian hasil belajar,Membuat RPP (Ratulangi, 2016).

2) Pelaksanaan

Adapun pelaksanaan dari kegiatan pra siklus dimulai dengan dengan kegiatan awal, selanjutnya kegiatan inti dan terahir kegiatan penutup. 
Kegiatan Awal;Pengucapan sapaan salam,Doa bersama,Absensi kehadiran siswa di dalam kelas,Dan review sejauh mana kemampuan siswa dalam memahami Trigonometri

Kegiatan Inti; Guru memberikan penjelasan tentang Trigonometri, Guru menugaskan siswa agar mengerjakan soal mengenai Trigonometri (Kusumaningsih, 2011). Kegiatan Penutup;Guru meminta siswa untuk mengumpulkan tugasnya,Guru menilai tugas siwa.Salam penutup

3) Pengamatan

Hasil belajar pada pra siklus pembelajaran Matematika tentang Trigonometri masih masih sangat rendah dan belum sesuai dengan yang diharapkan peneliti. Hal ini bisa dilihat pada tabel berikut (Nurzakiaty, 2015).

4) Refleksi

Berdasarkan hasil dari kegiatan pra siklus diatas dapat disimpulkan pada tahap Pra Siklus ini dikatakan kemampuan Siswa Dalam Memahami Trigonometri di Kelas X MIA masih rendah, hal ini disebabkan pembelajaran di kelas hanya bersifat transfer ilmu pengetahuan saja dan dilakukan secara konvensional dengan menyampaikan materi pelajaran sebanyak-banyaknya tanpa memperhatikan kebutuhan siswa. Pada siklus ini jumlah siswa yang tuntas belajar 19 siswa atau sekitar 76\%, angka tersebut belum memenuhi indikator kinerja yang di tentukan dalam ptk ini yaitu 85\%. Maka perlu adanya tidakan selanjutnya yaitu menerapkan model pembelajaran Cooperative Learning type STAD dengan Pendekatan Kontekstual pada siklus 1

\section{Hasil Penelitian Siklus 1}

Tahap siklus 1 di laksanakan pada tanggal 22 Januari 2018 dan 27 Januari 2018. Pada tahap ini pembelajaran di laksanakan dengan menerapkan model pembelajaran Cooperative Learning type STAD dengan Pendekatan Kontekstual dengan tahapan sebagai berikut

1) Perencanaan

Adapun perencanaan dalam siklus 1 ini sebagai berikut: Guru memberi pertanyaan: Apa yang dimaksud dengan tirgonometri? Guru membimbing siswa dalam pembentukan kelompok. Guru membagikan lembar kerja pada setiap kelompok. Guru menyajikan pelajaran.Guru memberi tugas pada kelompok untuk dikerjakan oleh angota kelompok. Anggota kelompok yang tahu menjelaskan pada anggota lainnya sampai semua anggota dalam kelompok itu mengerti (Ismaimuza \& Idris, 2020). Guru memberi kuis/pertanyaan kepada seluruh siswa. Pada saat menjawab pertanyaan siswa tidak boleh saling membantu.Guru menanggapi hasil kerja peserta didik. Guru memberi penghargaan kepada siswa yang mendapat nilai tertinggi. Guru membimbing siswa untuk membuat kesimpulan.Guru memberi tugas untuk minggu depan. Guru memberikan evaluasi (Rahmat, 2019). 
2) Pelaksanaan

Adapun pelaksanaan dari kegiatan pembelajaran siklus 1 pada pertemuan 1 dan 2 sebagai berikut:

Kegiatan Pendahuluan;Mengucapkan salam .Berdo`a sebelum belajar .Mengabsen kehadiran siswa .Apersepsi : Tanya jawab berbagai hal terkait dengan wawasan siswa mengenai materi yang akan diajarkan dan menyampaikan tujuan pembelajaran .Motivasi : Menjelaskan tujuan kompetensi yang ingin dicapai.

\section{Kegiatan Inti}

Eksplorasi: Guru memberi pertanyaan : Apa yang dimaksud dengan trigonometri ? (pertemuan 1) dan apa yang di maksud rasio trigonomteri? (pertemuan 2) (rasa ingin tahu);Menjelaskan trigonometri ? (pertemuan 1) dan rasio trigonomteri? (pertemuan 2). Guru membimbing siswa dalam pembentukan kelompok (disiplin, kerja sama)

Elaborasi;Guru membagikan lembar kerja pada setiap kelompok (disiplin).Guru menyajikan pelajaran.Guru memberi tugas pada kelompok untuk dikerjakan oleh angota kelompok. Anggota kelompok yang tahu menjelaskan pada anggota lainnya sampai semua anggota dalam kelompok itu mengerti.Guru memberi kuis/pertanyaan kepada seluruh siswa. Pada saat menjawab pertanyaan siswa tidak boleh saling membantu

Konfirmasi;Guru menanggapi hasil kerja peserta didik

Kegiatan penutup;Guru memberi penghargaan kepada siswa yang mendapat nilai tertinggi.Guru membimbing siswa untuk membuat kesimpulan.Guru memberi tugas untuk minggu depan.Guru memberikan evaluasi

3) Pengamatan

Selama kegiatan pembelajaran berlangsung, peneliti bertindak sebagai observer yang bertugas mengamati kegiatan pembelajaran dengan mengisi lembar observasi yang telah disusun sebelum melaksanakan kegiatan penelitian. Hal ini dilakukan untuk mengetahui peningkatan kemampuan siswa dalam memahami Trigonometri pada mata pelajaran Matematika . Pada kegiatan belajar mengajar ini guru menggunakan model pembelajaran cooperative learning type STAD dengan Pendekatan Kontekstual.

Berdasarkan hasil dari kegiatan siklus 1 diatas dapat disimpulkan pada tahap Siklus 1 ini dikatakan kemampuan Siswa Dalam Memahami Trigonometri di Kelas X MIA mulai menunjukkan adanya perubahan ke arah yang positif, yaitu jumlah siswa yang tuntas belajar dan mendapatkan nilai melebihi standar KKM lebih banyak di bandingkan dengan siklus sebelumnya. Pada siklus ini jumlah siswa yang tuntas belajar 20 siswa atau sekitar $80 \%$, meskipun ada peningkatan jumlah siswa namun angka tersebut masih belum memenuhi indikator kinerja yang di tentukan dalam ptk ini yaitu 85\%. Maka perlu adanya tidakan selanjutnya yaitu menerapkan model 
pembelajaran Cooperative Learning type STAD dengan Pendekatan Kontekstual pada siklus 2. Berikut ini adalah grafik perbandingan jumlah ketuntasan siswa pada pra siklus dan siklus 1 .

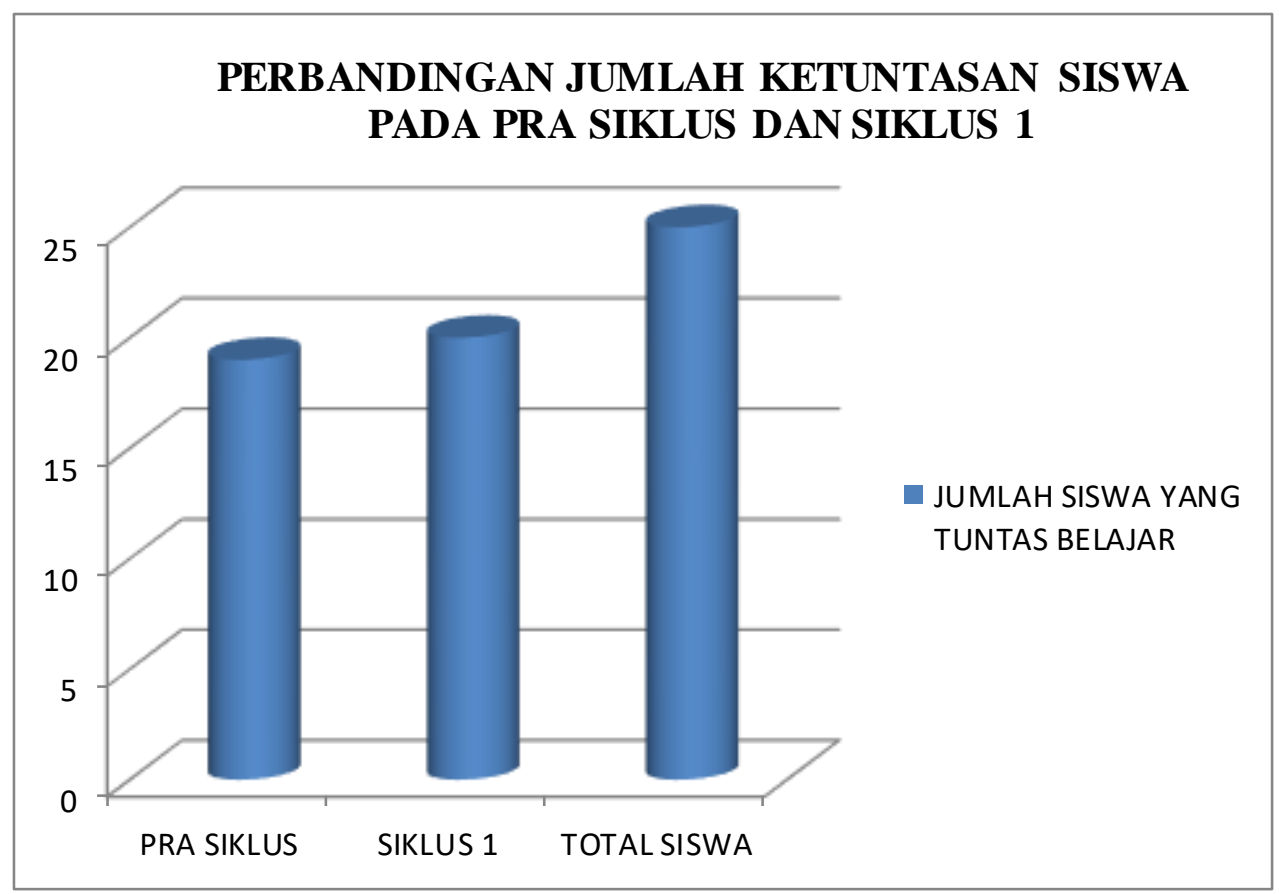

Grafik 1

Perbandingan Jumlah Ketuntasan Siswa Pada Pra Siklus Dan Siklus 1

\section{Hasil Penelitian Siklus 2}

Tahap siklus 2 di laksanakan pada tanggal 29 Januari 2018 dan 6 Februari 2018. Pada tahap ini pembelajaran di laksanakan dengan menerapkan model pembelajaran Cooperative Learning type STAD dengan Pendekatan Kontekstual dengan tahapan sebagai berikut

1) Perencanaan

Adapun perencanaan dalam siklus 2 ini sama dengan siklus 1. Hanya saja terdapat beberapa perbedaan yaitu pada siklus 2 ini materi yang di sampaikan lebih detail dan lebih banyak di bandingakan dengan siklus sebelumnya.

2) Pelaksanaan

Adapun pelaksanaan dari kegiatan pembelajaran siklus 2 pada pertemuan 3 dan 4 sebagai berikut;

Kegiatan Pendahuluan; Mengucapkan salam .Berdo`a sebelum belajar .Mengabsen kehadiran siswa .Apersepsi : Tanya jawab berbagai hal terkait dengan wawasan siswa mengenai materi yang akan diajarkan dan menyampaikan tujuan pembelajaran .Motivasi : Menjelaskan tujuan kompetensi yang ingin dicapai. 
3) Kegiatan Inti

Eksplorasi: Guru memberi pertanyaan : Apa yang dimaksud dengan rasio trigonometri? (rasa ingin tahu). Membahas tentang rasio trigonometri (pada pertemuan 3) dan rasio trigonometri untuk sudut-sudut di berbagai kuadran (pertemuan 4). Menjelaskan rasio trigonometri (pada pertemuan 3) dan rasio trigonometri untuk sudut-sudut di berbagai kuadran (pertemuan 4)

Mendiskusikan rasio trigonometri (pada pertemuan 3) dan rasio trigonometri untuk sudut-sudut di berbagai kuadran (pertemuan 4)

Guru membimbing siswa dalam pembentukan kelompok (disiplin, kerja sama)

4) Elaborasi

Guru membagikan lembar kerja pada setiap kelompok (disiplin)

Guru menyajikan pelajaran

Guru memberi tugas pada kelompok untuk dikerjakan oleh angota kelompok. Anggota kelompok yang tahu menjelaskan pada anggota lainnya sampai semua anggota dalam kelompok itu mengerti

Guru memberi kuis/pertanyaan kepada seluruh siswa. Pada saat menjawab pertanyaan siswa tidak boleh saling membantu

Konfirmasi;Guru menanggapi hasil kerja peserta didik

Kegiatan penutup; Guru memberi penghargaan kepada siswa yang mendapat nilai tertinggi. Guru membimbing siswa untuk membuat kesimpulan. Guru memberi tugas untuk minggu depan. Guru memberikan evaluasi

\section{5) Pengamatan}

Berdasarkan hasil pengamatan dapat di katakan bahwa kegiatan pembelajaran yang di lakukan pada siklus 2 ini meski sudh bisa di nyatakan berjalan lebih kondusif dan sudah sesuai dengan harapan peneliti. Hal tersebut di karenakan siswa sudah paham dengan penerapan model pembelajaran cooperative learning type STAD dengan Pendekatan Kontekstual, sehingga siswa masih sudah memahami apa yang harus di lakukannya.

Hasil belajar pada siklus 2 pada pembelajaran Matematika tentang Trigonometri menunjukkan adanya peningkatan. Hampir semua siswa mendapatkan nilai di atas KKM. Siswa yang tuntas terhitung lebih banyak lagi di bandingkan dengan perolehan hasil belajar pda pra siklus dan siklus 1 Hal ini bisa dilihat pada tabel berikut.

\section{Refleksi}

Berdasarkan hasil dari kegiatan siklus 2 diatas dapat disimpulkan pada tahap Siklus 2 ini dikatakan kemampuan Siswa Dalam Memahami Trigonometridi Kelas X MIA menunjukkan adanya peningkatan yang sangat baik. Pada siklus ini jumlah siswa yang tuntas belajar 22 siswa atau sekitar $88 \%$, angka tersebut sudah memenuhi indikator kinerja yang di tentukan 
dalam ptk ini yaitu 85\%. Maka di anggap tidak perlu adanya tidakan selanjutnya, dan penelitian ini berhenti pada siklus 2. Berikut ini adalah grafik perbandingan jumlah ketuntasan siswa pada pra siklus, siklus 1 dan siklus 2 .

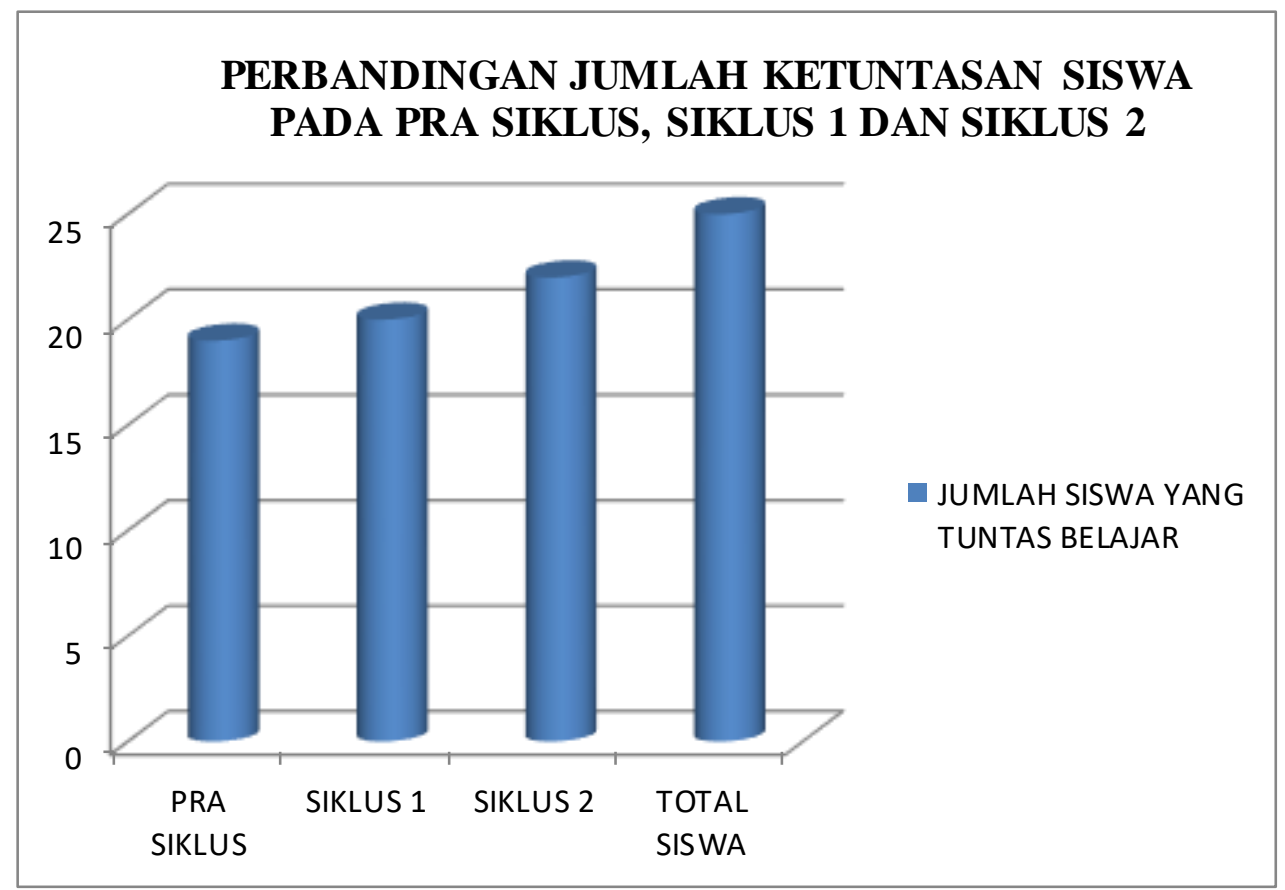

Grafik 2

Perbandingan Jumlah Ketuntasan Siswa Pada Pra Siklus, Siklus 1 dan Siklus 2

\section{B. Pembahasan}

\section{Pembahasan Siklus Pertama}

Pada proses pelaksanaan siklus ke-1 siswa diminta untuk mengikuti KBM dengan Model Pembelajaran Cooperative Learning type STAD dengan Pendekatan Kontekstual. Dengan Model Pembelajaran Cooperative Learning type STAD dengan Pendekatan Kontekstual yang menekankan pada aktivitas dan interaksi diantara siswa untuk saling memotivasi dan saling membantu dalam menguasai materi pelajaran guna mencapai prestasi yang maksimal maka siswa lebih semangat dan antusias dalam mengikuti pembelajaran (Suparsawan \& SD, 2020).

Dari hasil pengamatan, hasil nilai dan wawancara pada siklus I, Model Pembelajaran Cooperative Learning type STAD dengan Pendekatan Kontekstual secara efektif dapat meningkatkan kemampuan siswa dalam memahami Trigonometri di Kelas X MIA SMA Negeri 1 Sukapura Tahun Pelajaran 2017/2018. Pada siklus 1 ini jumlah siswa yang tuntas belajar mencapai 20 siswa, dengan prosentase ketuntan $80 \%$. 


\section{Pembahasan Siklus Kedua}

Penelitian tindakan kelas ini dilakukan dalam 2 siklus. Siklus kedua ini adalah siklus yang merupakan refleksi dari siklus pertama. Pada siklus ke II ini terdiri dari kegiatan perencanaan, pengamatan, dan refleksi tindakan. Pada siklus ini pelaksanaan Model Pembelajaran Cooperative Learning type STAD dengan Pendekatan Kontekstual hampir sama seperti yang di terapkan pada siklus I (Istiana et al., 2015). Dan hasil dari Model Pembelajaran Cooperative Learning type STAD dengan Pendekatan Kontekstual yang sudah di laksanakan menunjukkan adanya peningkatan kemampuan siswa dalam memahami Trigonometri di Kelas X MIA SMA Negeri 1 Sukapura Tahun Pelajaran 2017/2018. Pada siklus 2 ini jumlah siswa yang tuntas belajar mencapai 22 siswa, dengan prosentase ketuntasan $88 \%$.

\section{Kesimpulan}

Hasil penelitian yang telah di jelaskan pada BAB IV dengan metode penelitian yang di jelaskan pada BAB III dan dengan kajian toeri yang di jelaskan pada BAB II serta dengan latar belakang yang telah di jelaskan pada BAB I, maka peneliti membuat kesimpulan dari hasil penelitian yang dilakukan di Kelas X MIA SMA Negeri 1 Sukapura Tahun Ajaran 2017/2018, Yaitu: "Implementasi Model Pembelajaran Cooperative Learning Type STAD Dengan Pendekatan Kontekstual Untuk Meningkatkan Kemampuan Siswa Dalam Memahami Trigonometri di Kelas X MIA SMA Negeri 1 Sukapura Tahun Pelajaran 2017/2018" dapat kondusif dan berjalan dengan lancar.

Perbandingan hasil penelitian yaitu pada pra siklus jumlah siswa yang tuntas belajar hanya 19 siswa atau 76\%, kemudian pada siklus 1 meningkat menjadi 20 siswa atau $80 \%$, dan meningkat lagi pada siklus 2 menjadi 22 siswa atau $88 \%$. Dari penrbandingan hasil penelitian tersebut maka dapat di simpulkan bahwa, dengan konsep 4X pertemuan maka Model Pembelajaran Cooperative Learning type STAD dengan Pendekatan Kontekstual berdampak positif bagi proses peningkatan kemampuan siswa dalam memahami Trigonometri. 


\section{BIBLIOGRAFI}

Hamsi, N. (2016). Upaya Meningkatkan hasil belajar IPS dengan metode Ceramah Kelas V. Briliant: Jurnal Riset Dan Konseptual, 1(1), 63-67.Google Scholar

Ismaimuza, D., \& Idris, M. (2020). Penerapan Model Pembelajaran Penemuan Terbimbing Untuk Meningkatkan Hasil Belajar Siswa Pada Materi Perbandingan Trigonometri Dalam Segitiga Siku-Siku Di Kelas X Mia 1 Madrasah Aliyah Negeri 1 Palu. Jurnal Elektronik Pendidikan Matematika Tadulako, 8(1), 70-81. Google Scholar

Istiana, G. A., Saputro, A. N. C., \& Sukardjo, dan J. S. (2015). Penerapan Model Pembelajaran Discovery Learning untuk Meningkatkan Aktivitas dan Prestasi belajar pokok bahasan larutan penyangga pada siswa kelas xi ipa Semester II sma negeri 1 ngemplak Tahun pelajaran 2013/2014. Jurnal Pendidikan Kimia, 4(2), 6573. Google Scholar

Khasanah, D. R. A. U., Pramudibyanto, H., \& Widuroyekti, B. (2020). PendidikaDalam Masa Pandemi Covid-19. Jurnal Sinestesia, 10(1), 41-48. Google Scholar

Kusumaningsih, D. (2011). Upaya meningkatkan kemampuan berpikir kritis siswa kelas XC SMA N 11 Yogyakarta melalui pembelajaran matematika dengan pendekatan contextual teaching and learning (CTL) pada materi perbandingan trigonometri. Skripsi. Yogyakarta: UNY. Google Scholar

Novita, T. (2021). Penerapan Pendekatan Kontekstual Dalam Menggembangkan Kemampuan Menulis Cerpen Pada Siswa Ix A Di Smp Negeri 1 Tebing Tinggi Kabupaten Empat Lawang Provinsi Sumatera Selatan. Iain Bengkulu. Google Scholar

Nurzakiaty, I. (2015). Penerapan Model Pembelajaran Kooperatif Tipe Team Assisted Individualization (TAI) Dalam Pembelajaran Integral Di Kelas XII IPA-2 SMA Negeri 8 Banda Aceh. Jurnal Peluang, 3(2).

Palayukan, H. (2018). Analisis Kesalahan Siswa dalam Menyelesaikan Soal Perbandingan Trigonometri Pada Segitiga Siku-Siku Berdasarkan Kriteria Watson Di Kelas X SMA Katolik Rantepao. Inspiramatika, 4(1), 47-60. Google Scholar

Rahmat, P. S. (2019). Strategi Belajar Mengajar. PT. Scopindo Media Pustaka. Google Scholar

Ratulangi, T. (2016). Analisis Kemampuan Guru Mengelola Pembelajaran Tematik Menurut Kurikulum 2013 di SD Negeri 1 Sopai Kabupaten Toraja Utara. Daya Matematis: Jurnal Inovasi Pendidikan Matematika, 4(1), 13-19. Google Scholar

Suparsawan, I. K., \& SD, S. P. (2020). Kolaborasi Pendekatan Saintifik dengan Model Pembelajaran STAD Geliatkan Peserta Didik. Tata Akbar. Google Scholar 
Implementasi Model Pembelajaran Cooperative Learning Type Stad dengan Pendekatan Kontekstual untuk Meningkatkan Kemampuan Siswa dalam Memahami Trigonometri

Tkalčič, M. (2012). The superior-subordinate relationship and work climate in the Slovenian tourism industry. Academica Turistica-Tourism and Innovation Journal, 5(1), 31-45. Google Scholar

Yusuf, I., \& Asrifan, A. (2020). Peningkatan Aktivitas Kolaborasi Pembelajaran Fisika Melalui Pendekatan Stem Dengan Purwarupa Pada Siswa Kelas Xi Ipa Sman 5 YOGYAKARTA:(Improving Collaboration of Physics Learning Activities through the STEM Approach). Uniqbu Journal of Exact Sciences, 1(3), 32-48. Google Scholar

\section{Copyright holder:}

Meirina Ikayanti, Inayati (2021)

\section{First publication right:}

Syntax Idea

This article is licensed under:

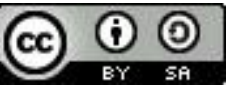

